\title{
Exploring and extending the synergy concept - a study of three acquisitions
}

\author{
Fohan Holtström \\ Department of Management and Engineering, Linköping University, Linköping, Sweden, and \\ Helén Anderson \\ Department of Marketing, Linnaeus University, Kalmar, Sweden
}

\begin{abstract}
Purpose - This study aims to contribute with an extended framework on synergy realisation in acquisitions. The study conceptualises synergy realisation after acquisitions, in interaction with other companies in a business network and that synergy can be the result of both intended and not intended actions.

Design/methodology/approach - The study is based on a company involved in acquisitions, being both the acquirer and the acquired. The data for analysis were collected through semi-structured interviews with managers involved in the described acquisition processes. The semi-structured interviews were guided by overarching themes to cover relevant areas of the described acquisitions.

Findings - This study develops a framework in which synergy is used as a concept in business networks. The framework offers a more dynamic perspective on acquisition processes and extends the view of acquisition performance beyond more financial and company internal aspects of acquisition processes. Further, the findings show that related companies such as customers and suppliers, play important roles in synergy realisation.

Practical implications - From a managerial perspective, the study shows the importance of understanding the underlying forces of integration processes.

Originality/value - The concept of synergy used in this study not only includes the companies integrated in an acquisition but also their business networks. Including the integrated companies and their business networks provides a more dynamic perspective from which to plan and realise synergy.
\end{abstract}

Keywords Adaptation, Mergers and acquisitions, Synergy, Coordination, Business networks

Paper type Research paper

\section{Introduction}

Synergy is frequently used to legitimise acquisitions (Mukherjee et al., 2004; Seth et al., 2000; Trautwein, 1990; Porter, 1987) in various types of industries, for example, Mylan's acquisition of Meda (Mylan, 2016) in the pharmaceutical industry, Pernod Ricard's acquisition of Vin and Sprit (Pernod, 2008) in the food industry, AT\&T's acquisition of Time Warner (AT\&T, 2016) in the communications industry and Volkswagen's acquisition of Scania (Volkswagen, 2014) in the manufacturing industry. The broadly used concept (Campbell and Sommers Luchs, 1998) lacks a common definition besides the general "two plus two equals five" (Garzella and Fiorentino, 2014; Sirower, 1997; Porter, 1987; Carter, 1977). Intended synergy is more commonly described than achieved synergy because synergy is not only difficult to attain (Zaheer et al., 2013; Goold and Campbell, 1998; Porter, 1987) but also to identify and measure (Garzella and Fiorentino, 2014; Zaheer et al., 2013; Goold and Campbell, 2000). In the literature, the realisation of synergy

The current issue and full text archive of this journal is available on Emerald Insight at: https://www.emerald.com/insight/0885-8624.htm

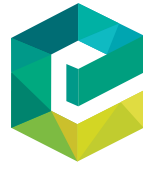

Journal of Business \& Industrial Marketing $36 / 13$ (2021) 28-41

Emerald Publishing Limited [ISSN 0885-8624] [DOI 10.1108/JBIM-09-2020-0420] appears complicated and not easily achieved (Garzella and Fiorentino, 2014; Zaheer et al., 2013; Zollo and Meier, 2008) often due to integration problems (Teerikangas and Thanos, 2018; Cartwright et al., 2012; Mirc, 2012), differences in organisational culture (Stahl and Voigt, 2008) or difficulties in presenting positive financial performance (King et al., 2004). Being an important measure of the expected outcome of acquisitions (Larsson and Finkelstein, 1999), there seems to be a difference between intentions and realisations (Zollo and Meier, 2008), which makes acquisition planning important (Epstein, 2005). In this study, we assume that synergy may emerge, intended or not intended because of an acquisition.

However, when companies acquire other companies, only the two involved companies seem to be in focus. From a business network perspective, companies are interconnected through business relationships and interactions (Ford and Håkansson, 2006). Business relationships are not static, they

(C) Johan Holtström and Helén Anderson. Published by Emerald Publishing Limited. This article is published under the Creative Commons Attribution (CC BY 4.0) licence. Anyone may reproduce, distribute, translate and create derivative works of this article (for both commercial and non-commercial purposes), subject to full attribution to the original publication and authors. The full terms of this licence may be seen at http://creativecommons.org/licences/by/4.0/legalcode

Received 4 September 2020

Revised 23 November 2020

Accepted 11 December 2020 
develop over time (Hadjikhani and LaPlaca, 2013) and companies react to changes and adapt as a consequence (Harrison et al., 2010; Håkansson and Snehota, 1989). In this way, a business network is dynamic (Ritter and Ford, 2004; Mattsson and Johanson, 2006) and the different actors adapt mutually to each other's activities (Anderson et al., 1994; Håkansson and Snehota, 1989). The literature on business networks shows that interconnectedness between companies such as customers and suppliers, may play important roles in realising synergy after an acquisition (Christofi et al., 2017; Degbey, 2015; Homburg and Bucerius, 2005; Quah and Young, 2005; Lusch et al., 2003; Anderson et al., 2001). Thus, including a business network perspective when studying synergy in acquisitions opens for new insights on integration effects. We propose that such interconnectedness may not only generate reactions such as levelling out intended synergies but may also generate new and unexpected ones. To understand such developments, it is not enough to evaluate a company's own resources without including its business relationships with other actors (Anderson et al., 1994).

The present study aims to contribute with an extended framework on synergy realisation in acquisitions drawing on literature from mainly two fields: business strategy and business networks. Thus, the study conceptualises how companies, after acquisitions, may realise synergy in interaction with other companies in a business network and that synergy can be the result of both intended and not intended actions.

The paper begins with synergy as a concept and links this concept to the literature on the development of acquisitions. The influence of business networks on acquisition is also explored. The conceptual framework addressed in the paper is presented thereafter. The methodology of the study is described followed by a section on the case, which presents three acquisitions in chronological order. The analysis is structured around the conceptual framework including the extended synergy in the dimensions; time (pre-acquisition and post-acquisition) and space (integrating firms and business network).

\section{Conceptual point of departure}

\subsection{Acquisitions and synergy realisation}

Synergy as a concept was introduced in the 1960s in the field of strategic management. Andersen et al. (1957) describe synergy as the superior use of resources to adapt more successfully to a changing environment with increased competitive pressure. A common illustration of synergy is two integrated units that are to achieve something more than the separate units can (Ansoff, 1965; Campbell and Sommers Luchs, 1998; Sirower, 1997). Synergy is one building block in company strategy (Ansoff, 1965) and during the 1960s and early 1970s, synergy was a motive for corporate strategic development through diversification (Porter, 1985; Rumelt, 1974). Rumelt's (1974) study on the existence of synergies amongst diversified companies, however, was later criticised by other scholars, including Seth (1990). Although later studies such as Zollo and Meier (2008), conceptualise a distinction between short- and long-term horizons in acquisition performance, synergy as a concept has remained a planning tool to justify an acquisition.

Most models in the field of mergers and acquisitions (M\&A) have evaluated synergy in acquisitions from the perspective of company financial development such as stock price, revenues, investments (Weber and Dholakia, 2000) or sources of value creation as evaluated with performance measurement (Gates and Véry, 2003). Ansoff (1965) explains synergy by examining its financial benefits - conceptualised around return on investment - using four main categories of synergy: sales, operations, investment and management. This model was further developed by Larsson (1990) by combining Ansoff (1965), Lorsch and Allen (1973), Lubatkin (1983) and Chatterjee (1986). Larsson's (1990) typology consists of market power synergy, operational synergy, management synergy and financial synergy. Itami (1987) brings a slightly different approach to synergy by dividing synergy into two distinct effects: a complementing effect (using resources more efficiently) and a synergy effect (using the companies' unique resources). In other words, attempts have been made to make the concept more precise.

Synergy has been discussed from a variety of perspectives. These perspectives include creating value (Larsson and Finkelstein, 1999; Haspeslagh and Jemison, 1991), strength and increased profitability (Kanter, 1989), sharing competencies and capabilities (Bresman et al., 1999; Goold and Campbell, 1998), managing purchasing synergy (Rozemeijer, 2000), the strength of market-related performance over cost savings (Homburg and Bucerius, 2005), acquisition outcome measured through different types of performance or effects on other stakeholders (Haleblian et al., 2009; Teerikangas and Thanos, 2018), integration process related to long-term firm performance (Zollo and Meier, 2008; Gates and Véry, 2003), synergy potential as an effect of the duration of the integration period (Oh and Johnston, 2020), the level of target autonomy and synergy potential (Zaheer et al., 2013), manager effects on acquisition performance (Teerikangas et al., 2011; Graebner, 2004) and serendipitous value creation (Graebner, 2004; Colman and Lunnan, 2011). Research on performance has almost solely addressed the organisational units involved in the integration following an acquisition or a merger.

Management identifies synergy potential early in the acquisition process. The process to identify synergy is labelled planned synergy, in other words, the goal of acquisition. Planning is a pre-acquisition phase and includes synergy intended to be realised. It has been argued to be important to identify the integrated business-critical activities early to realise synergy. These activities can include sharing technologies, production resources or coordinating marketing and distribution (Gates and Véry, 2003; Prahalad and Doz, 1986). These activities add to the dimensions in Ansoff's (1965) typologies of synergy but without a clear answer to how synergy is achieved. Goold and Campbell (2000) and later Gates and Véry (2003) present successful frameworks applied by companies for reviewing synergy potentials and they explain how to address the possibilities to realise synergy. There are several potential difficulties with realising an intended synergy in the post-acquisition phase: the motive for the acquisition may alter the expected outcome and there may be integration problems that affect the potential to create synergy (Zaheer et al., 2013; Goold and Campbell, 1998). Thus, the planned initiatives, pre-acquisition, may not appear while other effects or initiatives possibly emerge, post-acquisition. The reasons for this have been identified by several authors: organisations assume that efficiency is achieved by downsizing 
(Kanter, 1989), benefits are overestimated and costs underestimated (Goold and Campbell, 1998), potentials identified may not materialise following a thorough analysis (Itami, 1987; Sirower, 1997; Porter, 1987) or the models to effectively measure synergy potentials are not sufficiently developed (Garzella and Fiorentino, 2014).

Things may not turn out as planned even though management had planned for it, but synergies of a different kind can emerge in the post-acquisition phase, we label such synergy as unintended. Unintended synergy is a consequence of the actions initiated by the acquisition, not planned for by the acquirer or the acquired. Unintended synergy can be either wished for or not, but the consequence of the change arises at a later stage. Characterised by the initiation of activities in connection with an acquisition, unintended synergy can be produced by an internal reaction against the change intended by company management. Such effects can develop over time before a new company structure has been formed. Itami (1987) not only describes different types of synergy but also the dynamic perspective of synergy. Colman and Lunnan (2011) acknowledge the importance of being aware of the benefits that can occur unexpectedly by using the concept of serendipitous value creation. We take the same point of departure as Graebner (2004) and Colman and Lunnan (2011) and emphasise the importance of taking the unanticipated into account when evaluating an acquisition.

\subsection{Towards an extended perspective on the synergy} Interaction with other companies is included in our conceptualisation of synergy when we add a business network perspective to the concept. Within the field of strategy, the discussion of synergy as a performance concept is focused on the companies involved in the merger or acquisition. With our extension to business networks, we aim to acknowledge that, for example, also customers and suppliers to the integrating companies may be affected.

Figure 1 illustrates companies in relation to each other, the acquiring and the acquired companies' relationships to customers and suppliers. Irrespective of whether the acquiring and the acquired companies' actions affect other actors purposefully or not,

Figure 1 The relationships between an integrated company and its related actors

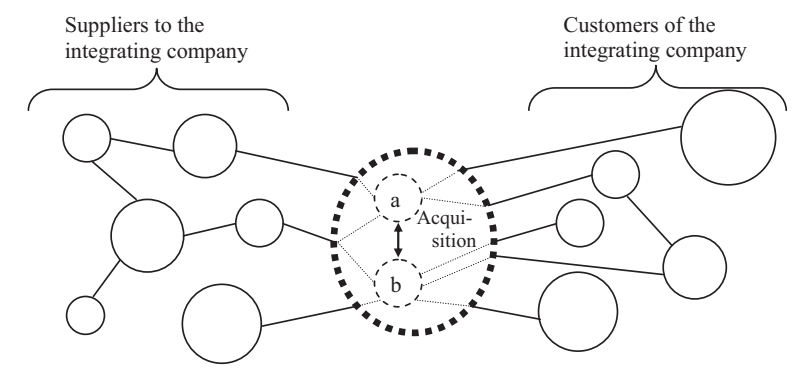

\footnotetext{
-. The activity, actors a and b involved in an acquisition, integrating into a new entity.

Relationships to other involved actors that might be affected by the change. This change may not be intended or a direct consequence, but these actors can also be linked.

Relationship between suppliers, company a, and/or company b, and customers prior to the acquisition.
}

any change in network position will spark a reaction amongst suppliers and customers (Anderson et al., 2013; Anderson et al., 2001; Öberg and Holtström, 2006). An actor will not only try to adapt to prevailing conditions in a business network but will, at the same time, also influence relationships with others (Ritter and Gemünden, 2003; Håkansson and Snehota, 1989). This demonstrates the extent of relatedness in business networks.

Business networks illustrate interaction in the relationships amongst actors (Håkansson, 1994). Increasingly, companies are choosing to purchase more of their value-added products from suppliers instead of manufacturing them themselves (Rozemeijer, 2000), so relationships evolve over time where reaction, action and adaptation to changes constitute the dynamics in business networks (Ritter and Ford, 2004; Håkansson and Snehota, 1989). These dynamics increase the importance of interaction amongst actors, voluntarily or involuntarily. Relationships amongst companies are often lingering ones, lasting at least a product's lifecycle (Mattsson and Johanson, 2006). This time perspective is critical for suppliers to understand in their negotiations with the integrated company. Dependencies amongst actors through business relationships are also affected by how, in what way and to what extent company relationships develop (Johanson and Mattsson, 1987; Håkansson and Ford, 2002; Gadde et al., 2003). Relationships are important for understanding synergy. Quah and Young (2005), for example, have found that retaining good customer relationships was of key importance in all the acquisitions they studied.

An important aspect of company relationships in relation to synergy is the creation of value (Ritter and Gemünden, 2003). It is important for a company to understand what value means to its customers (Ulaga, 2003). It is equally important for suppliers to understand how customers create value for a company (Walter et al., 2001). This importance increases as product lifecycles become shorter while the purchase value of the final products increases (Christopher and Lee, 2004; Rainbird, 2004). Changes in business relationships can affect other networks through affecting value and by creating chains of interrelated companies (Möller and Törrönen, 2003; Mirc, 2012). An important capability in a business network is to know which activities create value and to have the ability to coordinate these activities amongst network actors (Kothandaraman and Wilson, 2001). Thus, actors combine or pool their resources and capabilities through their relationships to create superior customer value (Kothandaraman and Wilson, 2001). This links to an extended view on synergy through the ambition to create something more together with other actors than as solitary units and as such also the question of distribution of the created value becomes important. This in itself is an interesting and important topic but beyond the scope of this article.

Therefore, we argue that there is a connection between synergy and value in the interaction in business networks. Inspired by Welch et al. (2011) and Rouzies et al. (2019) we take the context into account in analysing the consequences of efforts to generate synergy. Our argument is that the acknowledgement of interaction between companies in business networks in the pre-phase of acquisition affects synergy. We label this included synergy. Included synergy combines the integrated company's planned synergy activities, intended to bring about change in relation to other actors, with 
the integrated company's business relationships. Activities planned for by the integrators, pre-acquisition, with the intention to achieve wished-for activities are behind included synergy to influence other actors in favour of the integrated company's business relationships to these other actors.

Yet another dimension can be explored in the intention to realise synergy in the post-acquisition phase. We label this connected synergy. An actor acts and reacts to changes in a dynamic network with the objective of influencing their position within the business network. Connected synergy means that the changes initiated by the integrators generate activities to which the various actors, including the integrated company, adapt over time. Adaptation over time, in this context, is not an expression of passivity but can involve activities other actors perform in their attempts to have an impact on or enhance or counteract, the effects of change. The process of activities initiated by the acquiring company to achieve synergy also has consequences for actors with which the integrated company has relationships and these actors will react and/or adapt to such changes over time.

The two-by-two matrix in Figure 2 explains the perspective on synergy as follows (the grey areas in the matrix indicates our extended perspective): intended synergy (upper left) combines activities within the companies, the acquirer and the acquired, which have been identified/planned to be implemented during the pre-acquisition phases of the integration. Unintended synergy (upper right) consists of not planned activities that emerge over time between the directly involved parties in the past-acquisition phase. Included synergy (lower left) combines the pre-phases of acquisition, those planned, with the context of relationships with other actors exemplified as customers and suppliers. Finally, connected synergy (lower right) combines

Figure 2 An extended perspective on the synergy

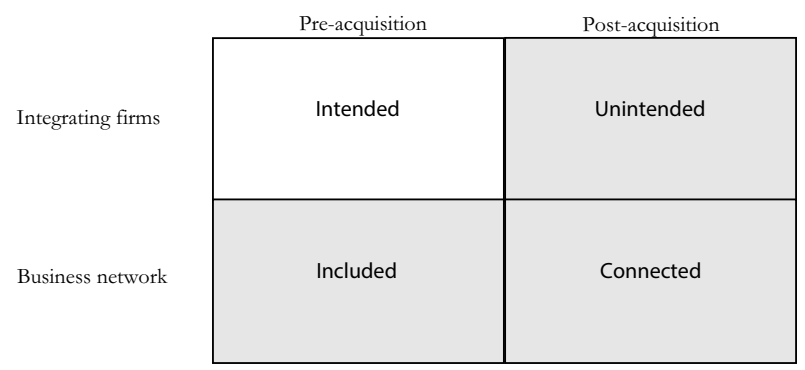

into a more dynamic perspective on synergy realisation including other actors' actions, reactions and adaptations. The introduced framework, including the four different types of synergy, is used to analyse three acquisitions.

\section{Method and research setting}

We used a single case study to "[...] explore a significant phenomenon under rare [...] circumstances" (Eisenhardt and Graebner, 2007, p. 27). We gained access to most of the leading managers and other centrally involved actors who were interviewed about the acquisitions while they still worked with the company or in a closely related position (retired but hired as a management consultant). The case included acquisitions where the focal company had the roles of being an acquirer and being acquired, which made the case unique and to some extent revelatory (Yin, 2018). The case was context-embedded (Yin, 2018), where the three separate acquisitions relate to each other, not isolated as single events but, adds complexity that intertwines the different acquisitions with each other.

\subsection{Introduction to the studied case}

This study examined the changes at Alfa through the acquisitions between 1997 and 2005 and includes besides Alfa, the companies named Beta, Delta and Gamma. The case comprises three acquisitions: Alfa's acquisition of Gamma in 1997, Alfa's acquisition of Beta in 1999/2000 and Delta's acquisition of Alfa in 2000, see the timeline in Figure 3 and includes the companies. The changes Alfa experienced can be characterised as follows: a horizontal acquisition of a manufacturer of the same size (Gamma), a concentric acquisition where Alfa acquired a company with a complementing product range (Beta) and a concentric acquisition where Alfa was acquired by Delta for the same reasons. Alfa was a producer of material-handling equipment, primarily electric warehouse trucks. The company was established in the mid-1940s in a Scandinavian country as a supplier of machine equipment to the building and construction industry and for the internal transportation needs of companies. Alfa soon started to develop its own forklift trucks and continuously evolved its operations within service and maintenance. Alfa was internationalised through acquisitions of distributors and producing companies and through the establishment of sales companies.

Alfa's expansion into the North American market had started with two acquisitions in the late 1980s and was further

Figure 3 Timeline of the illustrated acquisitions

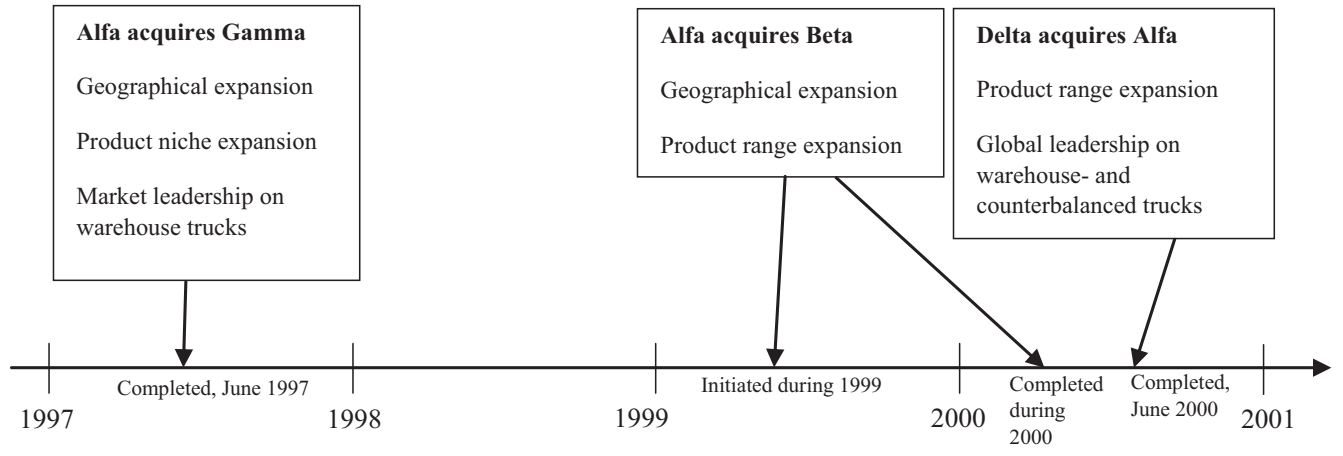


strengthened through the acquisition of Gamma in 1997, which made Alfa the largest producer of warehouse trucks in the world. The acquisition of Gamma had two main characteristics: it was an expansion within the same product niche, warehouse trucks; and it was a geographic expansion involving more countries and additional customer segments with specific product preferences. Alfa and Gamma manufactured the broadest product range worldwide, comprising all types of electric warehouse trucks.

The acquisitions of Gamma in 1997 and Beta two years later both complemented the product range from the acquirer's point of view. The acquisition of Beta provided Alfa with a range of counterbalanced [1] trucks to be produced under the Alfa brand. Delta's acquisition of Alfa was similar. Delta produced counterbalanced trucks and acquiring Alfa gave it worldwide coverage of warehouse trucks of all types. One reason Delta pursued this strategy was that its customers may have had a need for both types of trucks; a complete product range of both types would enhance customer relationships with no need to bring other suppliers of material handling equipment into the transaction.

The multiple acquisitions within the same company Alfa during a relatively short period of time increased the potential for different types of activities in the integrated companies such as changes in internal organisation, marketing, production, research and development. The level of complexity increased with multiple acquisitions and the potential to highlight multidimensional aspects of synergy. The rare circumstances mentioned by Eisenhardt and Graebner (2007) also apply to the rapidity with which these acquisitions were made; the first acquisition was made in June 1997 and the last acquisition was made in April 2000, less than three years after the first one. Alfa first acquired Gamma, which was the same size as Alfa. The final acquisition was executed by an Asian industry conglomerate, Delta. Both acquisitions led to "leadership" in the world market. Alfa became world-leading in warehouse trucks with the acquisition of Gamma. Delta became worldleading as a producer of forklift trucks with the acquisition of Alfa. The third acquisition, Beta, was also important but not on the same level as the other two; it was important more from a product/market perspective.

\subsection{Data collection}

The data consisted of semi-structured interviews guided by an inquiry form that covered all relevant areas (McCracken, 1988; Yin, 2018). In total, 15 interviewees participated in the study. The interviews lasted 1.5 to $3 \mathrm{~h}$. We interviewed the $\mathrm{CFO}$ on several occasions during the period of data collection. The number of interviews was 18 . All interviews were recorded and transcribed, which yielded valuable insight into the material during the analysis process (Eisenhardt, 1989). Interviews were conducted with managers on the corporate and business unit levels and interviewees included CEOs (both former and present), CFO, VP Marketing, VP OEM, VP Purchasing and Logistics, Manager for Manufacturing, Purchasing Manager, Manager for International Accounts and the Manager of R\&D, Table 1. All the interviewees represented the Alfa perspective on the acquisitions as both the acquirer and the acquired. It does mean that our empirical illustrations are one-sidedly presenting the Alfa-perspective and do not present the pictures from the companies Beta, Delta and Gamma. With their respective perspectives, we believe the empirical illustrations, to our conceptualisation, had been richer and more nuanced, however, not different in its four basic types.

Four themes were covered in the interviews: the corporate level and the respective roles of the interviewees prior, during and after the different acquisitions; background information about the other involved companies, together with the reasons behind the acquisitions; achieved synergies both planned and unexpected; and a broad perspective on integration, e.g. communication, organisational changes, restructuring efforts and synergy initiatives. The interviews also covered issues concerning market positions, product development and corporate strategy. In addition to this and with a more network perspective in mind, customer and supplier reactions and actions were discussed and elaborated on along with changes to the business network related to an industry under consolidation. Other sources of data were

Table 1 Interviews

\begin{tabular}{l}
\hline Role at the time of interview \\
\hline CEO and President Alfa \\
CFO Alfa \\
Former CEO and President Alfa \\
Former President Alfa International (division within Alfa) \\
President Alfa Europe (division within Alfa) \\
Vice President Purchasing and Logistics (Alfa) \\
Vice President Marketing, Alfa Europe (division within Alfa) \\
Vice President OEM, Alfa \\
Factory Manager, Alfa Products (factory of electrically powered trucks within Alfa) \\
Division Manager, Alfa Hand trucks (factory of hand trucks within Alfa) \\
Purchasing Manager Alfa \\
Manager, International Accounts, Alfa \\
Purchaser Alfa Products (factory for electrically powered trucks within Alfa) \\
Purchaser Alfa Hand trucks (factory of hand trucks within Alfa) \\
Business Planning and Administration - Trainee (linked to CFO Alfa)
\end{tabular}

Date

Summer, 2003

Fall, 2003

Spring, 2004

Spring, 2004

Spring, 2003

Summer, 2003

Fall, 2003

Summer, 2003

Summer, 2003

Spring, 2004

Summer, 2003

Spring, 2004

Spring, 2004

Winter, 2004

Winter, 2004

Winter, 2004

Spring, 2004 
also used in the study such as publicly accessible material on company webpages, annual reports, articles in the business press and books describing the historical developments of the involved companies.

The interviews started with a former CEO and the President of Alfa, who was involved in all the acquisitions. Based on these interviews, suggestions for further interviews were made to interview key staff members, who had been involved in the different acquisitions, or working with implementation activities. The study was reviewed by the company on various occasions and in several settings, including being read by top managers within the organisation during the preparation of the study. The study was also featured in different presentations and seminars.

The analysis of the interviews gave structure to the pattern of activities in categories of synergy, both within the integrated companies and in the integrated companies' relationships with other actors. The case study was quite detailed; the richness possible in a single case setting has been demonstrated by Siggelkow (2007, p. 22), who: “[...] applied the constructs to show how one can compactly describe a number of possible developmental paths and used Vanguard's history as an illustration". Inspired by Siggelkow (2007), our case study illustrates the different parts of the developed framework. Our research approach followed a continuous "confront [ing] theory with the empirical world" (Dubois and Gadde, 2002, p. 555), an iterative process in building our understanding of synergy in a wider context, to "discover new thing" (Dubois and Gadde, 2002, p. 559). This is similar to Welch et al. (2011), who discuss a contextualised explanation for " [...] a more complex understanding that recognises the contingent nature of causeeffect relationships" (Welch et al., 2011, p. 750). This means that the study was inspired both by theory and data in the development of our extended view on synergy. The case was used to develop our understanding of how synergy can be seen under changing conditions (Eisenhardt and Graebner, 2007; Siggelkow, 2007) and to illustrate synergy development in business networks.

\section{To acquire and to become acquired}

The first section of our findings highlights the elements of synergy in the three acquisitions. Our developed framework is, thereafter used to analyse an extended view on synergy.

\subsection{The first acquisition - Alfa acquires Gamma}

Prior to the acquisition, Alfa had a market share on the North American market of about 5\% and organic growth was limited. Growth in the European market was also limited. The best opportunity for growth within the product segment warehouse trucks - was to expand on the North American market. Gamma started in 1922 as a foundry and expanded into material handling equipment during the 1930s, was an ideal partner for the exchange of technologies and standardisation. Gamma was the market leader for warehouse trucks on the North American market prior to the acquisition.

A major motive for the acquisition of Gamma was to achieve a dominant position on a "new" geographic market and to gain access to established product standards for warehouse trucks in North America. Synergy from rationalisations was not included in the initial plan; they were considered something extra to realise later. Therefore, the integration between Alfa and Gamma proceeded cautiously and Alfa did not force any major changes. The operations in the acquired company were wellmanaged and profitable, with high growth potential. Alfa corporate management controlled its business units by monitoring various ratios and metrics (growth, profitability, cash flow) rather than through direct involvement in business operations.

The integration was limited, but some cooperative arrangements were made. The purchasing units evaluated similarities in components for potential common purchasing agreements. Purchasing was the most important area in which to identify synergy. "Better" prices owing to increased volumes were reached through negotiations with suppliers. Besides purchasing, insurance costs and the transfer of Alfa's model for financing customer forklift truck purchases were identified as a synergy early on and were transferred and implemented by Gamma. Gamma had a system for supplier evaluation that was later adopted by Alfa and eventually transferred to Delta. These synergy initiatives were mainly intended to be a transfer of knowledge. Synergy efforts focused on initiatives that were easy and quick to realise, as the ambition to fully integrate the companies was limited.

The post-acquisition integration did not identify numerous integration projects. However, several technology transfers were exchanged, for example, the alternating current technology developed by Alfa was transferred to Gamma, adding a new supplier for Gamma. There were also examples of transfer to Alfa; Gamma had an electrical engine supplier with which Alfa replaced some of its suppliers. It became possible to work in a more integrated manner with the product development of future products and to use more common components. However, there was no pressure to deliver more synergy than the low-hanging fruit identified earlier, as both companies were profitable.

Alfa had started the product development of a new forklift truck and was almost ready to manufacture a prototype when the acquisition was made. All product development projects were reviewed during the integration and it was found that Gamma had a similar product almost ready for production. The product developed by Gamma would fulfil Alfa's requirements and consequently, Alfa shut down its own project. Nevertheless, the project had not progressed as far as promised, i.e. it did not meet the specifications and had not been delivered. Nevertheless, the need for the product persisted, forcing Alfa to develop the product on its own with a three-year delay compared to the original timetable. In the meantime, competitors launched a similar forklift truck one year after Alfa closed its project. A forklift truck of this type is a long-term investment, 8 to 10 years and this experience demonstrate that there are long-term effects on customer relations when projects/products are delayed.

During the fall of 1997, purchase coordination showed positive results after only a few months, although the process to coordinate the purchasing function took two years to complete. This coordination started as a cooperation project, a review of all product areas with the potential to reduce costs for purchased materials. All major forklift components were systematically studied, including brake systems, hydraulic systems and electronics. It became obvious in certain areas 
such as steel, that there was no potential for synergy at all. Neither could synergies be realised as raw material or as machined steel components, primarily because freight costs for steel components were high relative to product prices. The synergy initiative was instead concentrated more on systemoriented components. The total value of the system components amounted to about $25 \%$ of the total purchased value. Some suppliers were changed, but the overall result was more favourable price levels for the purchased components.

\subsection{The second acquisition - Alfa acquires Beta}

Beta is a producer of counterbalanced trucks and at the time of the acquisition, it was part of a family-owned industry consortium in Europe. The forklift truck industry was under consolidation and high production volumes were critical to staying competitive. Beta had a production volume of about 2,000 forklift trucks in 1999, which mainly targeted a market in a South European country, however, this production volume was not viable in the long run. A profitable production level was at least 5,000 forklift trucks. For this reason, the owners of Beta were interested in selling the company to a long-term owner.

Alfa and Beta's relationship had developed with Alfa's expansion through sales companies in Europe. Alfa established a sales company in Beta's home market in 1988, which amassed major losses during the early years. Demand rose sharply in the 1990s, which turned the sales company establishment to profit. Around this time, it became important to develop aftermarket sales and not concentrate entirely on new product sales. Alfa saw Beta as a potential partner for Beta's domestic market. Beta maintained a sales force of about 60 representatives in its home market. Discussions with Beta led to the establishment of a jointly owned company in 1994, known as Alfa-Beta. The jointly-owned company was formed to represent both companies' products on Beta's domestic market. From an initial market share of $3 \%$ to $6 \%$, the joint venture grew in just a few years to between 15 and $20 \%$, which signalled synergy on Beta's domestic market. The cooperation had been in full operation for about five years before the acquisition was finalised. As a result of Alfa-Beta, the south European country where Beta had its headquarters became a market of major importance.

The Alfa sales organisation had long wanted a broader product range that also included counterbalanced trucks. Alfa had been searching for alternatives to produce under their own brand and had previously had agreements with other producers of counterbalanced trucks for some markets. However, Alfa had initially no interest in being the owner of the production capacity and developing new products but preferred to purchase Alfa-branded products from other producers. One important reason for this is that counterbalanced trucks are more standardised and offer lower margins than warehouse trucks. By comparison, warehouse trucks represented an investment in problem-oriented solutions and integrated service agreements, a situation that was far more profitable and differentiated from a deal for solely counterbalanced trucks.

Cooperation with Beta, however, originated in a need for Alfa to expand its presence on Beta's home market, which created market-related synergy. As such, the acquisition can be regarded as one means to gain access to a complete range of forklift trucks that includes counterbalanced trucks.
The acquisition originated in a market expansion initiative. Alfa acquired $45 \%$ of Beta in 1999 and the remaining 55\% in 2000 . In Scandinavia and the UK, Beta forklift trucks replaced forklift trucks previously purchased externally. The acquisition of Beta solved the problem of Alfa-branded counterbalanced trucks and Alfa achieved synergy effects from both product and market perspectives.

Synergy potential in purchasing between Alfa and Beta was limited. There were a few areas with synergy potential, specifically electric systems with engines and controllers and, to a lesser extent, gearboxes and other components. Alfa pursued joint negotiation agreements where the suppliers were the same. As the products made by Alfa and Beta were quite different from each other, their cooperation and potential to create synergy were about exchanging experience and sharing attempts to develop purchasing efficiencies, for example, by increasing the purchases of sub-systems produced by their suppliers. In some cases, these new purchasing arrangements caused the total number of suppliers to decrease and the synergy took place on a coordination level (fewer suppliers to handle).

\subsection{The third acquisition - Delta acquires Alfa}

Delta, an Asian Industry Conglomerate, included a variety of business areas such as engines, cars and forklift trucks, had identified a need to expand its product range of forklift trucks. Alfa had also a continuous need to expand its product range. Both Alfa and Delta had recognised each other as suitable for cooperation.

Delta contacted Alfa in 1997 to inquire if Alfa could produce electric-powered, Delta-branded warehouse trucks. One of the important questions raised in this process was if Alfa was prepared to develop a competitor to its own core businesses. Nonetheless, the idea was interesting to Alfa, which had identified a need for Delta's products. Alfa identified certain products that were available to Delta to fulfil the needs of Delta customers while, at the same time, not surrendering so much competitive advantage as to compete with Alfa's primary customers. Thus, both companies had identified potential for synergy with their respective products to make the types of forklift trucks more complete in relation to their customers. However, there were difficulties with this cooperation: Alfa did not gain access to Delta's product range, primarily due to internal circumstances at Delta. This was also a motive to keep Beta as part of Alfa, as the sales organisation needed counterbalanced trucks to achieve synergy potential towards customers.

Few changes were made directly after the acquisition, but in Europe, there were big differences between Delta and Alfa in their markets and distributorships, which were intentionally kept separate after the acquisition. Alfa had a fully owned sales organisation with direct contact with end-user customers and had a service organisation with 2,400 service technicians. Delta, in contrast, had distributors in every country (owned either by Delta or by private entrepreneurs). Delta distributed its products through the distributors to privately owned retailers, who also offered service and aftermarket sales. Service and aftermarket sales added significantly to company revenues and profits. With Delta's distribution channels, a major part of 
this business was in the hands of retailers, while Alfa controlled this part through direct customer contacts.

Following the acquisition of Alfa, the coordination of purchasing activities changed depending on the geographic area, for example, purchases in Europe for Delta, Alfa and Beta were coordinated to increase the potential for purchasing synergy. The co-ordination of European purchases in the early phases was concentrated on forklift truck engines and some electronic systems/components. A lead buyer system was introduced in the European organisation to achieve synergy. Through this system, a purchaser in one of the companies was appointed lead buyer who coordinated the internal need for a system or component and then led negotiations with suppliers from all the involved companies. Besides the lead buyer activity, there were other synergy initiatives, e.g. technical analyses of technical systems between the companies such as hydraulic systems. While it may be difficult to change existing systems to achieve synergy, the ideas behind such systems can be used for future product development and in the longer run, can create synergistic effects.

\section{Analysis}

By using the four types of synergy in the framework in Figure 2, our analysis gives examples of synergy with a focus on both the involved actors and examples in business relationships to other actors, before and after an acquisition. Table 2 presents an overview of the findings from the acquiring/acquired parties and the related firms together with a contextualised explanation for how different synergy activities can include business relationships between actors in business networks.

\subsection{Synergies from the integrated firms' perspective}

\subsubsection{Intended synergy}

Intended synergy comprises planned activities and an example of intended synergy is combined and coordinated procurement. The strategy in all three acquisitions was to increase the quantities purchased from some of the suppliers, thereby lowering purchase prices. Another example of intended synergy was found in the motives for acquiring Gamma. The objective was to gain a more dominant position in the North American market. The acquirer, Alfa, had developed a financial solution for customer purchases, which was then implemented in Gamma, the acquired firm. The intended synergy from the acquisition of Beta was a stronger position on the South European market and securing a more complete product range than previously. Similar arguments can be made for Delta's acquisition of Alfa through which it secured a dominant market position with a full range of all types of forklift trucks. In sum, an intended synergy is what the acquirer plans to achieve; these plans are initiated before the acquisition, during the planning for the acquisition and continue throughout the early phases of the integration.

\subsubsection{Unintended synergy}

Purchasing-related activities also have the potential for unintended synergy. In a review process of the supplier base after an acquisition, it may be possible to reduce the number of suppliers and concentrate volumes to fewer suppliers, and thus reach better agreements with those suppliers. Another example of unintended synergy is the transfer of knowledge of supplier evaluation systems. This knowledge was transferred from Gamma to Alfa, further developed and later transferred to Delta. Knowledge transferred to develop processes for working with suppliers as a professional purchasing organisation is another example of an unintended synergy.

There were attempts to coordinate forklift truck product development in Alfa's acquisition of Gamma, but those attempts were hindered by internal impediments. However, a second unintended synergy developed through the exchange of technologies. Alfa had developed alternating current technology for forklift trucks, which was transferred to Gamma and further developed for products on the North American market. This led to a new supplier for Gamma. The attempts to create common product development did not lead to any new products, however, the exchange of knowledge and technologies benefitted the relationship between the acquirer and the acquired. This, in turn, led to a third example of unintended synergy, the transfer of knowledge of financing customer projects. In addition, a review of insurance costs is an unintended synergy on the corporate level.

Another example of unintended synergy was found in the motives for the acquisition of Beta. Initially, the intended synergistic effects were market-driven through a stronger market position. However, an unintended synergy resulted over time; Alfa gained a full range of all types of forklift trucks for their other geographic markets through the forklift trucks produced by Beta. Thus, the complemented product range was an unintended synergy that was not initially intended, but it was a positive consequence of the acquisition and could replace other solutions in other geographic markets. In sum, unintended synergy is characterised by activities initiated through an acquisition that evolves over time as a consequence of the acquisition.

\subsection{Synergies from a business network perspective}

Leaving the internal company perspective, the analysis revealed other dimensions of the relationship amongst actors: synergy associated with sales is related to customers and synergy associated with purchasing is related to suppliers. Therefore, operating in a business network, activities initiated through acquisition also have consequences for other actors and can over time cause reactions from these actors such as an adaptation or a countermove. In addition, activities within the business network could have an impact on how the integrating companies act, react and adapt. Synergy in such context is described in two types: included and connected synergy.

\subsubsection{Included synergy}

In the integration after Alfa's two acquisitions, the purchasing departments reviewed their supplier agreements: who were the suppliers, what were the volumes and price levels? This is intended synergy, which has the potential to lower purchasing costs. The first example of included synergy is when suppliers drop their prices to gain larger volumes from the integrated company or to harmonise price levels in comparison with previous agreements with the separate companies. As a consequence, suppliers may lose customers if the integrated company chooses only one of the integrating companies' suppliers, when concentrating their purchase of certain goods to fewer suppliers. This leads to that some suppliers gain in 


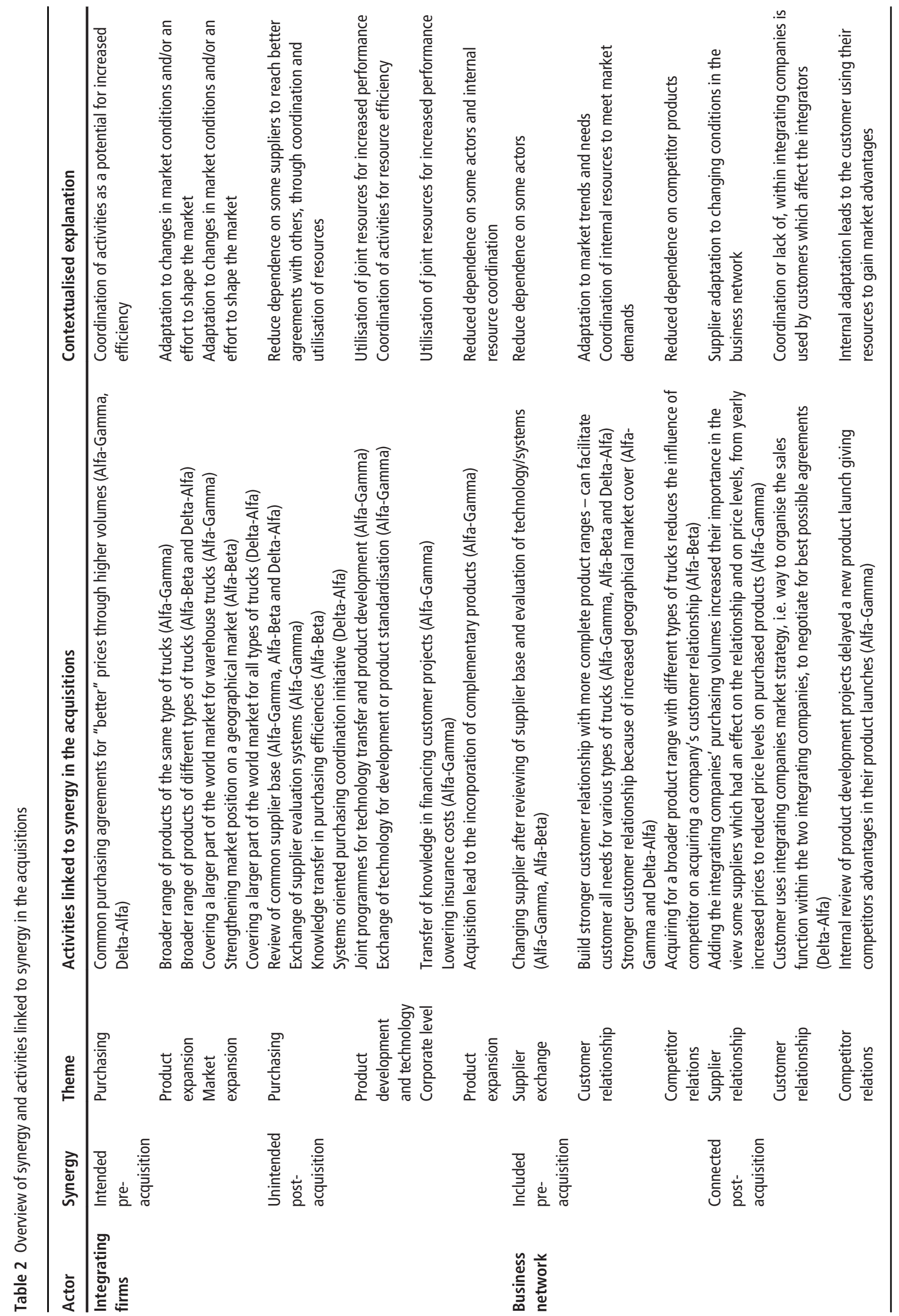


volumes and others lose their volumes. Thus, an included synergy was achieved in this acquisition through a change of suppliers; changing a supplier potentially reduces dependence on previously dominant suppliers.

Alfa's acquisition of Beta illustrates included synergy in relation to customer relationships. The acquisition motive originated from a need to reach a more stable market position, described as an intended synergy. Another acquisition motive, yet as important for Alfa, was to complement its product range with its own branded counterbalanced forklift trucks. The acquisition of Beta was an included synergy in Alfa's relationship to their customers, as the acquirer facilitated the customer option to purchase any type of forklift truck from one supplier. Similar findings concerning customer relationships were found in the other two acquisitions; a more complete product range facilitated customer needs for all categories of forklift trucks, regardless of standards or types of forklift trucks needed. Selling a broader product range is an adaptation to current prerequisites within a business network, which in the studied case, led to acquisitions both in terms of product range and geographic expansion. Geographic expansion has effects similar to product expansion where different product standards exist on different markets, which requires coordination within the integrating companies to meet customer demands on all markets. In a relationship with major customers who have a worldwide need for warehouse trucks, it is an advantage for the integrated company to offer a product range that includes different product standards designed for different markets and included synergy is achieved in customer relationships in this manner.

Acquiring for a broader product range could reduce the need for customers to develop a relationship with the integrating companies' competitors to obtain supplementary products to fulfil their need for forklift trucks. An included synergy is reached through a reduced dependence on customers' need for competitor products.

\subsubsection{Connected synergy}

Involvement does not necessarily mean that the integrating actors find the change desirable or as advantageous as an intended synergy would be. However, involvement does mean that, over time, there will be mutual adaptation amongst the involved actors within the business network. Therefore, we must understand the dynamics of the integrating companies' intentions to realise synergy with other actors' actions, reactions and adaptations. An example of connected synergy in the acquisition was in integrating companies' supplier relationships. The combined purchasing volumes changed supplier views of the integrated companies in comparison with two separate purchasing entities. The integrated company gained importance and was seen more as a strategic partner to the supplier. Firstly, this was achieved through reduced price levels and later with continuous price reductions over time because of the combined purchase volumes.

Connected synergy was found in Delta's acquisition of Alfa. Initially, the intention was not to integrate the distribution or sales organisations, but rather to maintain two different distribution channels to maximise market coverage/share. Alfa had a fully owned distribution network on the European market and Delta kept its model of a dealer network. The two different channels had access to certain products from both Alfa and Delta to become as complete in their product range as possible in both distribution channels. However, a strategy such as this has risks. This strategy led to a situation where different parts of the integrated company started to compete, the different sales organisations wanted to sell as much as possible. In integrating companies' customer relationships, this can be used by the customers to benefit from their offers from Delta and/or Alfa. The customers used these offers to gain a better deal in terms of products, service and maintenance. This might affect company profit of the integrating company if two internal sales organisations compete. The strategic intent was to maintain separate distribution channels to gain market shares, however, this resulted in a connected synergy in favour of the customers, which later led to an organisational adaptation to handle internal competition and prevent customers from leveraging. Some customer segments, for example, global companies renewing their fleet on a regular basis, were handled on an aggregated corporate level to maintain beneficial customer relationships. Managing customers on an aggregated level in the integrated company is a connected synergy. The intention of the connected synergy was to handle an internal competitive situation and adjust to customer expectations from the relationship with the integration between Delta-Alfa. This change was an adjustment of the integrated actors' business practices in their relationship with their customers.

A third example of connected synergy was the acquisition of Gamma, where a product development project in Alfa was closed. Gamma had a similar project that had progressed further than Alfa's project, which was in the early planning phase. However, the product development project in Gamma had not reached as far as originally described, which created advantages for Alfa's competitors and strengthened their market positions. Alfa's competitors benefitted from this connected synergy. Thus, the internal drive for synergy through coordinated product development did not turn out as expected and the development of what the market required took longer. This void was filled by competitors' newly developed products. As a connected synergy, this example turned out to be advantageous for competitors and a disadvantage for the integrated companies.

\section{Discussion and conclusions}

The point of departure in the present study was to assert a need for knowledge and understanding of synergy from the perspective of business networks in a contextualised conceptualisation. This is in line with Rouzies et al. (2019), who call for "[...] an embedded perspective on M\&As and address post-acquisition integration as unfolding in a context of co-evolving processes" (Rouzies et al., 2019, p. 280). We identified the interconnectedness between companies as important in how and in what way the companies can plan for and develop synergy after an acquisition (Christofi et al., 2017; Degbey, 2015; Homburg and Bucerius, 2005; Quah and Young, 2005; Lusch et al., 2003; Anderson et al., 2001). King et al. (2004) call for a need to develop acquisition research with reference to unidentified variables that explain acquisition performance. Our findings also show that related companies such as customers and suppliers, play important roles in 
synergy realisation. This positions our study in what Haleblian et al. (2009, p. 491) call an important dimension, the purpose of which is to increase our understanding of the effects and consequences of acquisitions. The concept of synergy used herein not only includes the companies integrated in an acquisition but also their business networks. Including the integrated companies and their business networks provides a more dynamic perspective from which to plan and realise synergy.

The conceptualisation of synergy through the typology presented in the paper supports what Graebner et al. (2017) emphasise as a need to include a temporal dimension in studying the effects of acquisitions. Thus, what is planned for, pre-acquisition, in terms of synergy may, over time, result in intended and unintended outcomes of an integration (Rouzies et al., 2019). The presented typology upholds the traditional view of synergy through the involved firms' intended or planned synergy initiatives (Ansoff, 1965) and unintended synergy or realised synergy, which indicate a temporal dimension (Graebner et al., 2017; Zollo and Meier, 2008). Through the inclusion of business networks, the typology includes the firms related to the integrated companies both from a more planned view, capturing the interaction between integrating firms and its network including a broader range of stakeholders (Haleblian et al., 2009). This is further enhanced with the more dynamic perspective of our identified connected synergy, which highlights the complexity and extends the potential effects of acquisitions beyond the integrated companies (Rouzies et al., 2019).

The framework offers a more dynamic perspective on acquisition processes and extends the view of acquisition performance beyond King et al. (2004) to measure performance through the value of acquired stocks (equity) and unfold "unidentified variables" (King et al., 2004, p. 280) including other stakeholders to understand the success or failure of acquisitions. Thus, from a conceptual perspective, this means expanding the traditional view of synergy (Ansoff, 1965) from something planned to be achieved by the acquirer as a result of acquisition to include the effects in connected business networks. The inclusion of the business network, as suggested in the categories included synergy and connected synergy, is a way to understand the implication of acquisition by extending the concept of synergy to actors in the connected business network.

The present case study illustrates and suggests a broader interpretation of synergy in which context was considered. Our study gives findings useful for both managerial implications and implications for research. For research, we suggest an extended framework to discuss synergy related to M\&As. It is about time, we claim, that one takes a step towards a more precise definition of synergy than "two plus two equals five". We suggest that the search for theoretical points of departure from different fields may help develop a new and broader understanding of what can render synergy. That, in turn, can provide definitions for performance measures both for integrating companies and for the development of value in a business network. Further studies should aim at specifying the definitions of suggested concepts through the lens of performance. Along with other authors, our choice of analytical concepts highlighted some dimensions while leaving others in shadow. One limitation, which also calls for further study, was the inclusion of other stakeholders such as customers and suppliers, to increase the understanding of synergy as suggested by the typology. A future study should follow stakeholders to integrating companies through the events of a post-acquisition process, what actions, reactions and adaptations are made from the perspectives of business network actors.

The study showed the importance of understanding the underlying forces of integration processes from a practical perspective. A practical implication of our study is the extended view for managers and board members of what to consider as relevant boundaries when discussing potentials for synergy in M\&As. Firstly, it is important to understand the underlying forces of integration processes that set into motion a chain of various activities. Reactions from related companies in a business network can be initiated. The effects and consequences of acquisition can vary over time, from an initial renegotiation of contracts with suppliers (to achieve more favourable price levels) to restructuring amongst suppliers (to deliver larger quantities or a broader range, of components). Secondly, stability and dependency in relationships can make changes in supplier relationships difficult if product development has been conducted in close cooperation with suppliers and, synergy might, therefore, be achieved only with future product development projects. Finally, acquisitions may lead to a need for related companies to review their own strategies before deciding how and whether or not to meet new conditions in the business network. So when planning for an acquisition or a merger one needs to include how to value the realisation of intended and unintended synergies, as well as the actions and reactions from other stakeholders in the business network.

\section{Note}

1 There are two different types of forklift trucks counterbalanced and warehouse. Counterbalanced forklift trucks are powered by combustion engines or electrical engines. Warehouse forklift trucks mainly have electrical engines, however, there are different standards depending on market conditions.

\section{References}

Andersen, T.A., Ansoff, H.I., Norton, F. and Weston, J.F. (1957), "Planning for diversification through merger", California Management Review, Vol. 1 No. 4, pp. 24-35.

Anderson, H., Havila, V. and Nilsson, F. (2013), Mergers and Acquisitions: The Critical Role of Stakeholders, Routledge Advances in Management and Business Studies, Routledge, London.

Anderson, H., Havila, V. and Salmi, A. (2001), "Can you buy a business relationship? On the importance of customer and supplier relationships in acquisitions", Industrial Marketing Management, Vol. 30 No. 7, pp. 576-586.

Anderson, J.C., Håkansson, H. and Johanson, J. (1994), "Dyadic business relationships within a business network context”, Fournal of Marketing, October, Vol. 58 No. 4, pp. 1-15. 
Ansoff, H.I. (1965), Corporate Strategy - An Analytic Approach to Business Policy for Growth and Expansion, McGraw-Hill.

AT\&T (2016), “At\&T to acquire time warner,' press release", 22 October 2016, available at: http://about.att.com/story/ att_to_acquire_time_warner.html

Bresman, H., Birkinshaw, J. and Nobel, R. (1999), "Knowledge transfer in international acquisitions", fournal of International Business Studies, Vol. 30 No. 3, pp. 439-462.

Campbell, A. and Sommers Luchs, K. (1998), Strategic Synergy, 2nd ed., Thompson Business Press, London.

Carter, J.R. (1977), "In search of synergy: a structureperformance test", The Review of Economics and Statistics, Vol. 59 No. 3, pp. 279-288.

Cartwright, S., Teerikangas, S., Rouzies, A. and Wilson-Evered, E. (2012), "Methods in M\&A - a look at the past and the future to forge a path forward", Scandinavian fournal of Management, Vol. 28 No. 2, pp. 95-106.

Chatterjee, S. (1986), "Types of synergy and economic value: the impact of acquisitions on merging and rival firms", Strategic Management fournal, Vol. 7 No. 2, pp. 119-139.

Christofi, M., Leonidou, E. and Vrontis, D. (2017), "Marketing research on mergers and acquisitions: a systematic review and future directions", International Marketing Review, Vol. 34 No. 5, pp. 629-661.

Christopher, M. and Lee, H. (2004), "Mitigating supply chain risk through improved confidence", International fournal of Physical Distribution Eo Logistics Management, Vol. 34 No. 5, pp. 388-396.

Colman, H.L. and Lunnan, R. (2011), "Organizational identification and serendipitous value creation in postacquisition integration", fournal of Management, Vol. 37 No. 3, pp. 839-860.

Degbey, W.Y. (2015), "Customer retention: a source of value for serial acquirers", Industrial Marketing Management, Vol. 46, pp. 11-23.

Dubois, A. and Gadde, L.E. (2002), "Systematic combining: an abductive approach to research", fournal of Business Research, Vol. 55 No. 7, pp. 553-560.

Eisenhardt, K. (1989), "Building theories from case study research", The Academy of Management Review, Vol. 14 No. 4, pp. 532-550.

Eisenhardt, K. and Graebner, M. (2007), "Theory building from cases: opportunities and challenges", Academy of Management fournal, Vol. 50 No. 1, pp. 25-32.

Epstein, M.J. (2005), "The determinants and evaluation of merger success", Business Horizons, Vol. 48 No. 1, pp. 37-46.

Ford, D. and Håkansson, H. (2006), "The idea of business interaction", The IMP fournal, Vol. 1 No. 1, pp. 4-27.

Gadde, L.E., Huemer, L. and Håkansson, H. (2003), "Strategizing in industrial networks", Industrial Marketing Management, Vol. 32 No. 5, pp. 357-364.

Garzella, S. and Fiorentino, R. (2014), “A synergy measurement model to support the pre-deal decision making in mergers and acquisitions", Management Decision, Vol. 52 No. 6, pp. 1194-1216.

Gates, S. and Véry, P. (2003), "Measuring performance during M\&A integration”, Long Range Planning, Vol. 36 No. 2, pp. 167-185.

Goold, M. and Campbell, A. (1998), "Desperately seeking synergy”, Harvard Business Review, Vol. 78 No. 5, pp. 131-143.
Goold, M. and Campbell, A. (2000), "Taking stock of synergy a framework for assessing linkages between businesses", Long Range Planning, Vol. 33 No. 1, pp. 72-96.

Graebner, M. (2004), "Momentum and serendipity: how acquired leaders create value in the integration of technology firms", Strategic Management fournal, Vol. 25 No. 89, pp. 751-777.

Graebner, M., Heimeriks, K.H., Huy, Q.N. and Vaara, E. (2017), "The process of postmerger integration: a review and agenda for future research", Academy of Management Annals, Vol. 11 No. 1, pp. 1-33.

Hadjikhani, A. and LaPlaca, P. (2013), "Development of B2B marketing theory", Industrial Marketing Management, Vol. 42 No. 3, pp. 294-305.

Håkansson, H. (1994), "Economics of technological relationships", in Engwall, L. (Ed.), Four Decades of Uppsala Business Research, Acta Universitatis Upsaliensis, Studia Oeconomaie Negotiorum, Vol. 44, pp. 337-354.

Håkansson, H. and Ford, D. (2002), "How should companies interact in business networks?", fournal of Business Research, Vol. 55 No. 2, pp. 133-139.

Håkansson, H. and Snehota, I. (1989), "No business is an island the network concept of business strategy", Scandinavian fournal of Management, Vol. 5 No. 3, pp. 187-200.

Haleblian, J., Devers, C.E., McNamara, G., Carpenter, M.A. and Davison, R.B. (2009), "Taking stock of what we know about mergers and acquisitions: a review and research agenda", Fournal of Management, Vol. 35 No. 3, pp. 469-502.

Harrison, D., Holmen, E. and Pedersen, A.C. (2010), "How companies strategise deliberately in networks using strategic initiatives”, Industrial Marketing Management, Vol. 39 No. 6, pp. 947-955.

Haspeslagh, P.C. and Jemison, D.B. (1991), Managing Acquisitions: Creating Value through Corporate Renewal, The Free Press, New York, NY.

Homburg, C. and Bucerius, M. (2005), “A marketing perspective on mergers and acquisitions: how marketing integration affects postmerger performance", fournal of Marketing, Vol. 69 No. 1, pp. 95-113.

Itami, H. (1987), Mobilizing Invisible Assets, Harvard University Press, Cambridge, MA.

Johanson, J. and Mattsson, L.G. (1987), "Interorganizational relations in industrial systems: a network approach compared with the transaction-cost approach", International Studies of Management E Organization, Vol. 17 No. 1, pp. 34-48.

Kanter, R.M. (1989), When Giants Learn to Dance, Simon \& Schuster, New York, NY.

King, D.R., Dalton, D.R., Daily, C.M. and Covin, J.G. (2004), "Meta-analyses of post-acquisition performance: indications of unidentified moderators", Strategic Management fournal, Vol. 25 No. 2, pp. 187-200.

Kothandaraman, P. and Wilson, D.T. (2001), "The future of competition: value-creating networks", Industrial Marketing Management, Vol. 30 No. 4, pp. 379-389.

Larsson, R. (1990), "Coordination of action in mergers and acquisition - interpretive and systematic approaches towards synergy", Dissertation. Lund Studies in Economics and Management, 10.

Larsson, R. and Finkelstein, S. (1999), "Integrating strategic, organizational, and human resource perspectives on mergers 
and acquisitions: a case survey of synergy realization", Organization Science, Vol. 10 No. 1, pp. 1-26.

Lorsch, J.W. and Allen, S.A. III. (1973), Managing Diversity and Interdependence - An Organizational Study of Multidivisional Firms, Harvard University Press, Boston.

Lubatkin, M. (1983), "Mergers and the performance of the acquiring firm", The Academy of Management Review, Vol. 8 No. 2, pp. 218-225.

Lusch, R.F., O'Brien, M. and Sindhav, B. (2003), “The critical role of trust in obtaining retailer support for a supplier's strategic organizational change", fournal of Retailing, Vol. 79 No. 4, pp. 249-258.

McCracken, G. (1988), Qualitative Research Methods, Sage, London.

Mattsson, L.G. and Johanson, J. (2006), "Discovering market networks", European fournal of Marketing, Vol. 40 Nos 3/4, pp. 259-274.

Mirc, N. (2012), "Connecting the micro- and macro-level: proposition of a research design to study post-acquisition synergies through a social network approach", Scandinavian Fournal of Management, Vol. 28 No. 2, pp. 121-135.

Möller, K.E. and Törrönen, P. (2003), "Business suppliers' value creation potential: a capability-based analysis", Industrial Marketing Management, Vol. 32 No. 2, pp. 109-118.

Mukherjee, T.K., Kiymaz, H. and Baker, H.K. (2004), "Merger motives and target valuation: a survey of evidence from CFOs", Fournal of Applied Finance, Vol. 14 No. 2, pp. 7-24.

Mylan (2016), “Mylan to acquire meda,' press release”, $10 \mathrm{Feb}$ 2016, available at: http://newsroom.mylan.com/2016-02-10Mylan-to-Acquire-Meda

Öberg, C. and Holtström, J. (2006), "Are mergers and acquisitions contagious?", Fournal of Business Research, Vol. 59 No. 12, pp. 1267-1275.

Oh, J.H. and Johnston, W. (2020), "How post-merger integration duration affects merger outcomes", fournal of Business and Industrial Marketing, Article in Press.

Pernod, R. (2008), "Acquisition of vin \& sprit march 31st 2008", available at: www.pernod-ricard.com/en/ download/file/fid/6791/

Porter, M.E. (1985), Competitive Advantage - Creating and Sustaining Superior Performance, The Free Press.

Porter, M.E. (1987), "From competitive advantage to corporate strategy", Harvard Business Review May/fune, pp. 43-59.

Prahalad, C.K. and Doz, Y.L. (1986), The Multinational Mission: Balancing Local Demands and Global Vision, The Free Press, New York, NY.

Quah, P. and Young, S. (2005), "Post-acquisition management: a phases approach for cross-border M\&As", European Management fournal, Vol. 23 No. 1, pp. 65-75.

Rainbird, M. (2004), “A framework for operations management: the value chain", International fournal of Physical Distribution \& Logistics Management, Vol. 34 Nos 3/4, pp. 337-345.

Ritter, T. and Ford, D. (2004), "Interactions between suppliers and customers in business markets”, in Håkansson, H., Harrison, D. and Waluszewski, A. (Eds), Rethinking Marketing: Developing a New Understanding of Markets, Wiley.
Ritter, T. and Gemünden, H.G. (2003), "Interorganizational relationships and networks: an overview", fournal of Business Research, Vol. 56 No. 9, pp. 691-697.

Rouzies, A., Colman, H.L. and Angwin, D. (2019), "Recasting the dynamics of post-acquisition integration: an embeddedness perspective", Long Range Planning, Vol. 52 No. 2, pp. 271-282.

Rozemeijer, F. (2000), "How to manage corporate purchasing synergy in a decentralised company? Towards design rules for managing and organising purchasing synergy in decentralised companies", European fournal of Purchasing $\mathcal{E}$ Supply Management, Vol. 6 No. 1, pp. 5-12.

Rumelt, R.P. (1974), Strategy, Structure and Economic Performance, Harvard University Press, Cambridge, MA.

Seth, A. (1990), "Sources of value creation in acquisitions: an empirical investigation", Strategic Management fournal, Vol. 11 No. 6, pp. 431-446.

Seth, A., Song, K.P. and Pettit, R. (2000), "Synergy, managerialism or hubris? An empirical examination of motives for foreign acquisitions of US", fournal of International Business Studies, Vol. 31 No. 3, pp. 387-405.

Siggelkow, N. (2007), "Persuasion with case studies", Academy of Management fournal, Vol. 50 No. 1, pp. 20-24.

Sirower, M. (1997), "“The synergy trap", in de Wit, B. and Meyer, R. (Eds), Strategy - Process, Content, Context, 2nd ed., Thomson Business Press.

Stahl, G. and Voigt, A. (2008), "Do cultural differences matter in mergers and acquisitions? A tentative model and examination", Organization Science, Vol. 19 No. 1, pp. 160-176.

Teerikangas, S. and Thanos, I.C. (2018), "Looking into the 'black box' - unlocking the effect of integration on acquisition performance", European Management fournal, Vol. 36 No. 3, pp. 366-380.

Teerikangas, S., Véry, P. and Pisano, V. (2011), "Integration managers' value-capturing roles and acquisition performance", Human Resource Management, Vol. 50 No. 5, pp. 651-683.

Trautwein, F. (1990), "Merger motives and merger prescriptions", Strategic Management fournal, Vol. 11 No. 4, pp. 283-295.

Ulaga, W. (2003), "Capturing value creation in business relationships: a customer perspective", Industrial Marketing Management, Vol. 32 No. 8, pp. 677-693.

Volkswagen (2014), "Volkswagen group seeks to acquire all shares of scania", Volkswagen Press Release, February 21.

Walter, A., Ritter, T. and Gemünden, H.G. (2001), "Value creation in buyer-seller relationships: theoretical considerations and empirical results from a supplier's perspective", Industrial Marketing Management, Vol. 30 No. 4, pp. 365-377.

Weber, J.A. and Dholakia, U.M. (2000), "Including marketing synergy in acquisition analysis", Industrial Marketing Management, Vol. 29 No. 2, pp. 157-177.

Welch, C., Piekkari, R., Plakoyiannaki, E. and PaavilainenMäntymäki, E. (2011), "Theorising from case studies: towards a pluralist future for international business research", Fournal of International Business Studies, Vol. 42 No. 5, pp. 740-762.

Yin, R.K. (2018), Case Study Research and Applications - Design and Methods, Sage Publications. 
Zaheer, A., Castañer, X. and Souder, R. (2013), "Synergy sources, target autonomy, and integration in acquisitions", Fournal of Management, Vol. 39 No. 3, pp. 604-632.

Zollo, M. and Meier, D. (2008), "What is M\&A performance?", Academy of Management Perspectives, Vol. 22 No. 3, pp. 55-77.

\section{Further reading}

Goold, M. and Campbell, A. (2003), "Structured networks towards the well-designed matrix", Long Range Planning, Vol. 36 No. 5, pp. 427-439.

\section{About the authors}

Johan Holtström is an Assistant Professor in Industrial Marketing at the Department of Management and Engineering, Linköping University Sweden. His research interests cover mergers and acquisitions, synergy, business relationships, business models and business model innovation. His work has been published in Fournal of Business Research, Fournal of Business-to-Business Marketing and Fournal of Strategy and Management, etc. Johan Holtström is the corresponding author and can be contacted at: johan.holtstrom@liu.se

Helén Anderson is a Full Professor of Business Administration at Linnaeus University School of Business and Economics, Sweden. Her research covers market and technology strategy issues and primarily how markets aspects affect the development of technology and products; in brief, how technology reaches market acceptance. The second field of research concerns the dynamics of business networks and has recently focused on the effects that acquisitions and mergers have on customers and suppliers. Her work has been published in Industrial Marketing Management, Scandinavian Fournal of Management, Supply Chain Management, Fournal of Brand Management and Fournal of Business-to-Business Marketing, etc. 